\title{
THE CO-MOVEMENT BETWEEN SHARIAH COMPLIANT AND SECTORIAL STOCK INDEXES PERFORMANCE IN BURSA MALAYSIA
}

\author{
Mohammad \\ Sahabuddin ${ }^{1+}$ \\ (iD) Junaina \\ Muhammad $^{2}$ \\ Mohamed Hisham \\ Dato' hjYahya ${ }^{3}$ \\ Sabarina \\ Mohammed Shah ${ }^{4}$ \\ Mohammad \\ Mizanur Rahman ${ }^{5}$
}

\author{
${ }^{1,5}$ PhD Student, Faculty of Economics and Management, Universiti Putra \\ Malaysia, Malaysia \\ ${ }^{2}$ Email: sahabuddingme@gmail.com \\ ${ }_{2, s, 4}$ Senior Lecturer, Faculty of Economics and Management, Universiti Putra \\ Malaysia, Malaysia
}

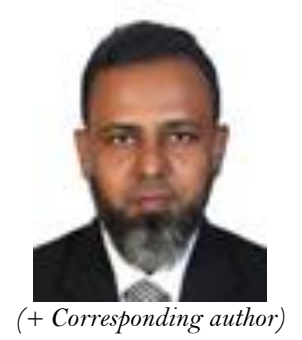

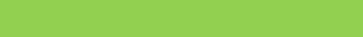

Article History

Received: 7 February 2018 Revised: 15 March 2018 Accepted: 21 March 2018 Published: 30 March 2018

\section{Keywords}

Co-movement

Shariah compliant stock index

Sectorial stock indices

Co-integration approach

Portfolio

Strategies.

JEL Classification: Goo, G200, G29.

\begin{abstract}
Islamic financial market is the growing innovation of global financial market which moves together with conventional and sectorial counterpart in many countries. As the fastest growing investment component, Shariah compliant stock index in Bursa Malaysia has picked up positive momentum and attracted more attention to the investors, policy makers, issuers and researchers. The main objective of this study is to investigate the co-movement between Shariah compliant stock and sectorial stocks indexes performance in Bursa Malaysia using a standard time series techniques. For understanding a long run and short run co-movement among the Shariah compliant stock index, composite stock index and sectorial stock indexes, a co-integration approach, Vector Error Correction Model (VECM) have been applied respectively in this study. In addition, Granger causality test have been adopted to determine the leadlag relationship. The findings show that in the long run, Shariah compliant index stock price and sectorial indexes stock price move together but in short run, speed of adjustment varies among the variables. Ganger causality test shows that there are bidirectional, unidirectional and no causality relationships between Shariah compliant and sectorial indexes.
\end{abstract}

Contribution/ Originality: This study contributes to investigate the co-movement and show the performance between Shariah compliant and sectorial stock indexes in bursa Malaysia which has a significant implication into a possible diversification strategies that impact the risk-return relationship or the expected rate of return in a portfolio investment.

\section{INTRODUCTION}

The Shariah compliant stock market is a part of the Islamic financial system as well as global financial systems which has drawn an extra attention not only to Muslim investors but also to Non-Muslims investors due to its rapid and phenomenal growth. Islamic financial market is the novelty of global financial market which moves together with their conventional as well as sectorial counterpart. As the fastest growing component of the global 
financial systems, Shariah compliant stock market has picked up positive momentum and now is attracting diverse investors and issuer's attention as a viable alternative (Rizvi and Arshad, 2017). Shariah compliant stocks are the equities which meet all of the compliance of Shariah law and regulation. Though in many countries the Islamic stock market runs successfully as an alternative and parallel counterpart but it fundamentally differs from the conventional one. Shariah compliant stocks are asset backed financial instruments which apply an approach of capital raising movements for investors to participate in risk-sharing and profit-sharing but strongly prohibited (Interest), Riba, (Uncertainty) Gharar and (Gambling) Maysi. Investors always want to maximize their expected return and minimize the risk but result depends on global geopolitical uncertainty, environmental and macroeconomics factors (Albaity and Ahmad, 2011). A rational investor always tries to make a balance between his expected return and risk factors. Shariah compliant stock index performance differs from sectorial stock indices which depends on the different investment time horizons (Alaoui et al., 2016). An optimum portfolio diversification strategy helps to ensure the benefits of investing and financing in stock markets. A Prime asset allocation comforts to mitigate the risk. Since late $2 \mathrm{O}^{\text {th }}$ century, the global financial markets have been increasing the trade ties and economics synchronization. The demand of products and services is growing tremendously among cross countries investors. Malaysia has established dual capital market structures which encompass the conventional capital market and the Islamic capital market. Islamic finance system in Malaysia has grown steadily with a small Islamic saving sector pilgrim fund from 1963 to become the third largest in the global Islamic finance industry and one of the most developed Islamic banking market in the world (Islamic, 2011). As of the end of first quarter 2016, Shariah compliant stocks were $74 \%$ of total stocks and market capitalization was USD $\$ 342.7$ billion on Bursa Malaysia which showed the highest for any exchange globally (Bursa Malaysia, 2016). FTSE group have lunched their world renowned indices jointly with Bursa Malaysia from 26 June, 2006. Bursa Malaysia's main market included all Malaysian companies' but FTSE categorizes their indices in various sectors for choosing the better option to the investors. For an appreciation of fast and noteworthy development of rising economies, investors are ready to take diversification benefits and high return by channelizing their funds to the stock markets.

The study of co-movement has led to an extensive area of research interest and motivated to design portfolio allocation and risk mitigation for different sectors and stock indices in Malaysia. The analysis of co-movement among the stock markets has extended the interests of policy makers, investors as well as researchers not only in Malaysia but also all over the world for practical implication of risk management and resources mobilization (Mensi et al., 2017). Most of the study examined the Shariah compliant stock indices performance using CAPM model for examining risk-return performance using Sharpe Index, Treynor Index and Adjusted Jensen Alpha ration Albaity and Ahmad (2008). Current study contributes to the literature on the issue of performance and co-movement of Shariah compliant stock indices using a standard time series techniques. The present study differs from other studies on the context of sectorial indices. Most of the prior studies were conducted on main market indices. The results of this study is significant for investors, policy makers and portfolio managers for investment decision and portfolio diversification from Shariah compliant indices, Conventional composite index and Commodities indices.

\section{LITERATURE REVIEW}

The findings of the prior studies provided contradictory evidence within the context of Shariah compliant stock indices performance. Some of the researchers found that Shariah compliant stocks outperform the conventional one and some of the researchers found that Shariah compliant stocks underperform than the conventional counterpart (Dharani and Natarajan, 2011). However, there are very few studies conducted on the co-movement of Shariah compliant stock index and sectorial stock indices performance in Bursa Malaysia. Hoque (2007) examined the comovement of Bangladesh stock market with developed (U.S.A, Japan) and developing (India) countries by using daily data from January 1990 to December 2000. They employed JJ test of co-integration, Vector Error Correlation Model (VECM) and Impulse Response Function (IRF) techniques and found that there was a co-integration among 
the variables. Therefore, there was no diversification benefit from cross border investigation. Girard and Hassan (2008) analyzed the performance and integration between FTSE Shariah and conventional indices by using multivariate co-integration analysis, Sharpe ratio, Treynor ratio, Jensens alpha, Fama's measures. They found that FTSE Shariah indices and conventional indices were integrated and both indices had the same level of risk reward and portfolio diversification benefits during the overall period of study span. Albaity and Ahmad (2008) investigated the short term and long term movements of both Kuala Lumpur Shariah Index (KLSI) and the Kuala Lumpur Composite Index (KLCI) on risk and return performance during the study period 1999-2005 by employing cointegration tests. They found that the two indices are significantly dependent on each other and there is no evidence that significantly differentiates the risk and return performance between these two indices. Majid and Kassim (2010) examined the integration among five Islamic stock markets namely: Malaysia, Indonesia, Japan, the UK and the US. They found that investors can gain benefits by diversifying the Islamic stock markets among economic groupings such as developed and developing countries stock market. Albaity and Ahmad (2011) examined the significance of relationship in return and know the reaction of treatment on return to the selected same firm specific variable like market capitalization, market-to-book ratio, price-earnings ratio, market risk and total debt between Shariah and Non-Shariah firms in Kuala Lumpur Shariah Index (KLSI) with the Kuala Lumpur Composite Index (KLCI) using panel data techniques on 300 observations for the period of 2000 to 2006 . They found that market size and marketto-book ratio are the most influential factors for Shariah compliant firms return but beta and market-to-book ratio are the most significance variable for determining Non-Shariah firms return. Guyot (2011) used the eighteen Shariah and conventional regional and world indices under broad perspective on Dow Jones family. The result is that there is no co-integration between Shariah and Conventional indices. This means that there is no long run association among the variables and therefore, portfolio diversification benefits exist over the period of time for foreign investors. Dharani and Natarajan (2011) analyzed the performance of Shariah indices and Conventional indices in India from January 2007 to December 2010. They used CAPM techniques like various ratio under risk adjusted measurement. The result found that although the Islamic indices underperformed however, they are comparatively stable as compared to the conventional indices. Karim et al. (2014) examined bidirectional and unidirectional relationship between Shariah compliant stock market and composite stock market in Malaysia from 2000 to 2010. They used various performance ratios like Sharpe ratio, Treynor ratio, Adjusted Jensen's Alpha Index Performance and Modified Sharpe Ratio and found that Shariah compliant stock indices perform better that conventional indices. Besides, researchers found that there was a bidirectional causality relationship between the two markets (Abdullah et al., 2016) measured the relationship between Islamic stock indices (Indonesia, Malaysia, Philippine, Singapore, and Thailand) and selective sectors of products (crude oil, corn and gold) by using the cointegration test. They found that there was a co-integrating relationship between variables and diversification benefits will be reduced in the long run due to the variables tending to move together in the same direction. Alaoui et al. (2015) investigated the co-movement dynamics using recent wavelet techniques at different times and scale horizon in Dubai Islamic Financial Market (DFM-UAE) index return with their counterpart regional Islamic indices return. They found that DFM_UAE, and (GCC and Saudi) move together in the same direction in the long run at same level of risk and volatility with the Global Sukuk index. Wavelet techniques indicated a strong nonhomogeneous correlation across scale and different periods of time. Rizvi and Arshad (2014) used multivariate GARCH DCC technique and examined that Islamic indices have contributed more than reluctant alternatives. This study showed that Islamic indices has negative correlation with their counterparts during the crisis period. Kim and Sun (2017) conducted an empirical research paper using DCC and ADCC model for a time span of 2000-2014 on 12 Chinese sectors and the S\&P 500. The findings of that study showed that a conditional correlation varies across the sectors. 


\section{METHODOLOGY}

\subsection{Econometric Method}

In this study, we used a standard time series econometrics analysis unit root test, multivariate co-integration test and Granger causality test to find out the logical outcome among research variables which will fulfill the research fundamental objectives.

\subsection{Data}

This study employed data which is the daily closing stock prices from FTSE Bursa Malaysia EMAS Shariah index, Conventional FTSE Bursa Malaysia KLCI composite index and ten sectorial indices (construction, Consumer product, Finance, Industrial, Plantation, Production, Properties, Trade and Services, Technology and Tin and Mining) in Bursa Malaysia. Total observation for each financial market stock indices is 2610. The observations were obtained from the Thomson-Reuters DataStream for the time period from 28 February 2007 to 28 February 2017.

Table-1. List of Selected indices (variables) of this study

\begin{tabular}{l|l|l}
\hline Indices & Details & $\begin{array}{l}\text { Symbol(Log } \\
\text { Form })\end{array}$ \\
\hline FBMEMAS & FTSE BURSA MALAYSIA EMAS SHARIAH INDEX & LEMAS \\
\hline FBMKLCI & FTSE BURSA MALAYSIA KLCI INDEX & LKLCI \\
\hline CONSTRUCTN & KUALA LUMPUR SECTORAL CONSTRUCTION - PRICE INDEX & LCONT \\
\hline CONSUMER & $\begin{array}{l}\text { KUALA LUMPUR SECTORAL CONSUMER PROD. - PRICE } \\
\text { INDEX LCUCU }\end{array}$ & \\
\hline FINANCE & KUALA LUMPUR SECTORAL FINANCE - PRICE INDEX & LFINA \\
\hline INDUSTRIES & KUALA LUMPUR SECTORAL INDUSTRIAL - PRICE INDEX & LINDS \\
\hline IND \& PROD & $\begin{array}{l}\text { KUALA LUMPUR SECTORAL INDUSTRIAL PROD. - PRICE } \\
\text { LINDP }\end{array}$ & \\
\hline PLANTATION & KUALA LUMPUR SECTORAL PLANTATIONS - PRICE INDEX & LPLNT \\
\hline PROPERTIES & KUALA LUMPUR SECTORAL PROPERTIES - PRICE INDEX & LPRPT \\
\hline TECHNOLOGY & KUALA LUMPUR SECTORAL TECHNOLOGY - PRICE INDEX & LTECH \\
\hline TIN \& MINING & KUALA LUMPUR SECTORAL TIN \& MINING - PRICE INDEX & LTINM \\
\hline TRAD/SERV & KUALA LUMPUR SECTORAL TRADE \& SERVICE - PRICE & LTRDS \\
\hline SNDEX & \\
\hline
\end{tabular}

Source: DataStream 29 February, 2017

\subsection{Empirical Framework}

In order to investigate whether indices move together or not, we used a unit-root test of Dickey-Fuller $(\mathrm{ADF})$ as a starting point for the co-integration analysis following Engle and Granger (1987). The lag length for the time series analysis is determined by choosing the lag length given by the minimum Akaike Information Criteria and Schwarz Information Criteria. To investigate the co-movement of Shariah compliant stock indices with the conventional ones and ten sectorial indices in Bursa Malaysia, this study applies time series analysis of cointegration, Vector Error Correction Model (VECM) and Ganger Causality techniques. Co-integration test have been used to examine the long-run relationship between Shariah compliant stock index and sectorial indices. VECM have been used in evaluating short-run dynamic interactions and Granger causality shows the bidirectional, unidirectional and no causality among the variables.

\subsection{Empirical Results and Discussion}

Due to the non-stationary nature of stock price indices, it is difficult to measure the co-movement of stock price return between different markets and different stock indices by using traditional econometric model. That is why the researcher endeavour to transform the data into stationary process by calculating daily returns from price indices as log differences in price: 
Table-2. Descriptive Summary

\begin{tabular}{|c|c|c|c|c|c|c|c|c|c|c|c|c|}
\hline & LEMAS & LKLCI & LFINA & LINDP & LINDS & LPLNT & $\begin{array}{l}\text { LPRP } \\
\mathbf{T}\end{array}$ & $\begin{array}{l}\text { LTEC } \\
\text { H }\end{array}$ & LTINM & LTRDS & $\begin{array}{l}\text { LCON } \\
T\end{array}$ & $\begin{array}{l}\text { LCNS } \\
\mathrm{U}\end{array}$ \\
\hline MEAN & 0.0073 & 0.0058 & 0.0070 & 0.0066 & 0.0054 & 0.0090 & 0.0067 & -0.0018 & -0.0003 & 0.0053 & 0.0030 & 0.0126 \\
\hline MAXIMUM & 1.770 & 1.850 & 2.294 & 2.761 & 3.074 & 5.082 & 2.697 & 3.824 & 14.814 & 1.909 & 3.091 & 1.412 \\
\hline MINIMUM & -4.916 & -4.334 & -3.532 & -3.063 & -4.343 & -4.722 & -4.199 & -3.975 & -5.851 & -4.440 & -7.453 & -2.192 \\
\hline STD. DEV. & 0.339 & 0.325 & 0.361 & 0.353 & 0.339 & 0.477 & 0.438 & 0.575 & 0.960 & 0.328 & 0.506 & 0.257 \\
\hline SKEWNESS & -1.536 & -1.157 & -0.652 & -0.977 & -0.740 & -0.347 & -0.627 & -0.036 & 2.297 & -1.105 & -1.624 & -0.821 \\
\hline KURTOSIS & 24.262 & 18.897 & 11.916 & 12.569 & 17.793 & 19.958 & 12.773 & 8.374 & 36.399 & 19.282 & 28.196 & 9.169 \\
\hline JARQUE-BERA & \begin{tabular}{|l}
50168.0 \\
8 \\
\end{tabular} & \begin{tabular}{|l}
28053.7 \\
3
\end{tabular} & 8827.60 & \begin{tabular}{|l|}
10367.6 \\
7
\end{tabular} & $\begin{array}{l}24026 . \\
08\end{array}$ & $\begin{array}{l}31315.4 \\
5\end{array}$ & $\begin{array}{l}10553 . \\
08\end{array}$ & 3139.86 & $\begin{array}{l}123558.1 \\
0\end{array}$ & $\begin{array}{l}29348.6 \\
4 \\
\end{array}$ & $\begin{array}{l}70158.9 \\
8\end{array}$ & $\begin{array}{l}4430.7 \\
0\end{array}$ \\
\hline $\begin{array}{l}\text { OBSERVATIO } \\
\text { NS }\end{array}$ & 2609 & 2609 & 2609 & 2609 & 2609 & 2609 & 2609 & 2609 & 2609 & 2609 & 2609 & 2609 \\
\hline
\end{tabular}

Table 2 provides to the summary of descriptive statistics of daily return for the stocks and sectorial indices. All indices show positive momentum of daily return. From the summary of descriptive statistics displayed, individual Financial Sector index has the highest return compared to others stocks and sectorial indices but EMAS Shariah index has the highest mean return respectively as compared to Kuala Lumpur Composite index (KLCI). It means that comparatively Shariah indices contributes a higher return compared to conventional index. Financial (FINA) sector also shows the highest volatility, on other hand Technology (TECH) shows a least volatile sector. This result does not differ from the theoretical statement that the higher the risk (Standard deviation), the higher the return (mean).

LEMAS

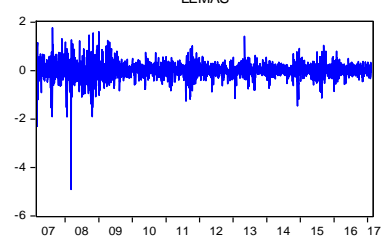

LFINA

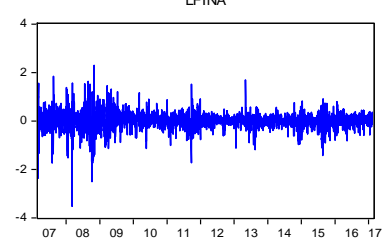

LPRPT

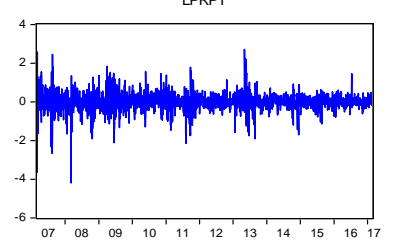

LKLCI

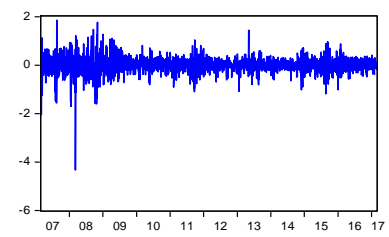

LINDP

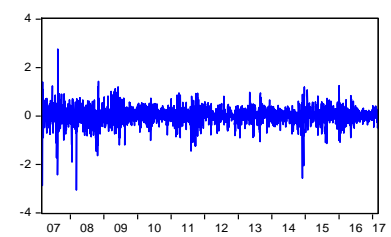

LTECH

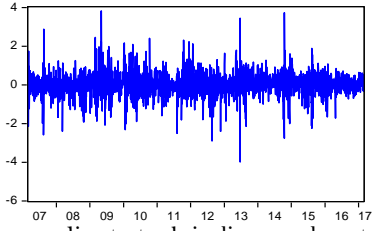

LCONT

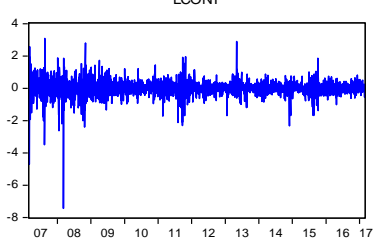

LINDS

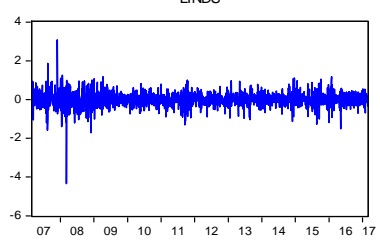

LCNSU

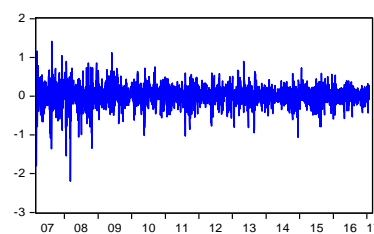

LPLNT

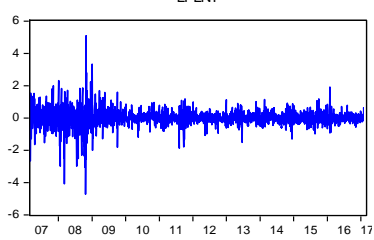

Figure-1. Shariah compliant stock indices and sectorial indices performance in Bursa Malaysia (Log form). Source: DataStream 29 February, 2017

Table-3. Correlation Matrix

\begin{tabular}{|c|c|c|c|c|c|c|c|c|c|c|c|c|}
\hline & EMAS & KLCI & FINA & INDP & INDS & PLNT & PRPT & TECH & TINM & TRDS & CONT & CNSU \\
\hline EMAS & 1 & & & & & & & & & & & \\
\hline KLCI & 0.984 & 1 & & & & & & & & & & \\
\hline FINA & 0.938 & 0.980 & 1 & & & & & & & & & \\
\hline INDP & 0.968 & 0.933 & 0.874 & 1 & & & & & & & & \\
\hline INDS & 0.957 & 0.926 & 0.861 & 0.938 & 1 & & & & & & & \\
\hline PLNT & 0.852 & 0.881 & 0.856 & 0.786 & 0.792 & 1 & & & & & & \\
\hline PRPT & 0.945 & 0.945 & 0.914 & 0.909 & 0.876 & 0.781 & 1 & & & & & \\
\hline TECH & 0.122 & 0.044 & -0.076 & 0.274 & 0.255 & -0.066 & 0.138 & 1 & & & & \\
\hline TINM & 0.807 & 0.799 & 0.755 & 0.800 & 0.786 & 0.640 & 0.870 & 0.283 & 1 & & & \\
\hline TRDS & 0.995 & 0.984 & 0.939 & 0.966 & 0.954 & 0.833 & 0.957 & 0.147 & 0.828 & 1 & & \\
\hline CONT & 0.777 & 0.765 & 0.693 & 0.797 & 0.806 & 0.658 & 0.845 & 0.505 & 0.840 & 0.804 & 1 & \\
\hline CNSU & 0.934 & 0.929 & 0.927 & 0.898 & 0.883 & 0.771 & 0.834 & -0.076 & 0.675 & 0.920 & 0.573 & 1 \\
\hline
\end{tabular}


Table-3 shows that all the variables (indices) are strongly correlated with each other. This means that all variables have a significant influence on one another. The result shows that there are strong correlations between EMAS and KLCI. But from sectorial indices TRDS and INDP shows very strong correlation to EMAS respectively.

Table-4. Unit root test

\begin{tabular}{|c|c|c|c|c|c|c|c|c|c|c|c|c|}
\hline & EMAS & KLCI & FINA & INDP & INDS & PLNT & PRPT & TECH & TINM & TRDS & CONT & CNSU \\
\hline \multicolumn{13}{|l|}{ Level } \\
\hline $\mathrm{ADF}$ & $\begin{array}{l}-1.2784 \\
--2.8624\end{array}$ & $\begin{array}{l}-1.3374 \\
-2.8624\end{array}$ & $\begin{array}{l}-1.2313 \\
-2.8624\end{array}$ & $\begin{array}{l}-0.8608 \\
-2.8624\end{array}$ & $\begin{array}{l}-2.0092 \\
-2.8624\end{array}$ & $\begin{array}{l}-2.3040 \\
-2.8624\end{array}$ & $\begin{array}{l}-1.3242 \\
-2.8624\end{array}$ & $\begin{array}{l}-1.8810 \\
-2.8624\end{array}$ & $\begin{array}{l}-2.2464 \\
-2.8624\end{array}$ & $\begin{array}{l}-1.1737 \\
-2.8624\end{array}$ & $\begin{array}{l}-1.9682 \\
-2.8624\end{array}$ & $\begin{array}{l}-1.3298 \\
-2.8624\end{array}$ \\
\hline PP & $\begin{array}{l}-1.2581 \\
-2.8624 \\
\end{array}$ & $\begin{array}{l}-1.2158 \\
-2.8624 \\
\end{array}$ & $\begin{array}{l}-1.1670 \\
-2.8624 \\
\end{array}$ & $\begin{array}{l}-0.9050 \\
-2.8624 \\
\end{array}$ & $\begin{array}{l}-1.9077 \\
-2.8624 \\
\end{array}$ & $\begin{array}{l}-2.3013 \\
-2.8624 \\
\end{array}$ & $\begin{array}{l}-1.4106 \\
-2.8624 \\
\end{array}$ & $\begin{array}{l}-2.1536 \\
-2.8624 \\
\end{array}$ & $\begin{array}{l}-2.2826 \\
-2.8624 \\
\end{array}$ & $\begin{array}{l}-1.1257 \\
-2.8624 \\
\end{array}$ & $\begin{array}{l}-1.8131 \\
-2.8624 \\
\end{array}$ & $\begin{array}{l}-1.2899 \\
-2.8624\end{array}$ \\
\hline \multicolumn{13}{|c|}{$\begin{array}{l}1^{\text {st diffe }} \\
\text { rence }\end{array}$} \\
\hline $\mathrm{ADF}$ & $\begin{array}{l}-45.6755 \\
-2.8624 * \\
\end{array}$ & $\begin{array}{l} \\
46.0928 \\
- \\
2.8624 *\end{array}$ & $\begin{array}{l}- \\
45.6154 \\
- \\
2.8624 *\end{array}$ & $\begin{array}{l} \\
46.5098 \\
- \\
2.8624 *\end{array}$ & $\begin{array}{l}- \\
47.6089 \\
- \\
2.8624^{*}\end{array}$ & \begin{tabular}{|l|} 
\\
44.5071 \\
- \\
$2.8624^{*}$
\end{tabular} & $\begin{array}{l} \\
31.4644 \\
- \\
2.8624^{*}\end{array}$ & \begin{tabular}{|l|} 
\\
47.0955 \\
- \\
$2.8624^{*}$
\end{tabular} & $\begin{array}{l}- \\
56.8439 \\
- \\
2.8624 *\end{array}$ & $\begin{array}{l}- \\
47.3417 \\
- \\
2.8624^{*}\end{array}$ & $\begin{array}{l}-48.2213 \\
-2.8624 *\end{array}$ & $\begin{array}{l}-47.8396 \\
-2.8624^{*}\end{array}$ \\
\hline $\mathrm{PP}$ & $\begin{array}{l}-45.83922 \\
-2.8624^{*}\end{array}$ & $\begin{array}{l}- \\
46.0903 \\
- \\
2.8624^{*}\end{array}$ & $\begin{array}{l}- \\
45.6082 \\
- \\
2.8624^{*}\end{array}$ & \begin{tabular}{|l} 
\\
47.0322 \\
- \\
$2.8624 *$
\end{tabular} & $\begin{array}{l} \\
47.6112 \\
- \\
2.8624 *\end{array}$ & $\begin{array}{l}- \\
44.5668 \\
- \\
2.8624 *\end{array}$ & $\begin{array}{l}- \\
45.4595 \\
- \\
2.8624 *\end{array}$ & $\begin{array}{l}- \\
47.7729 \\
- \\
2.8624^{*}\end{array}$ & \begin{tabular}{|l} 
\\
56.8439 \\
- \\
$2.8624 *$
\end{tabular} & $\begin{array}{l}- \\
47.3848 \\
- \\
2.8624 *\end{array}$ & $\begin{array}{l}- \\
48.25282 \\
-2.8624 *\end{array}$ & $\begin{array}{l}-48.2687 \\
-2.8624 *\end{array}$ \\
\hline
\end{tabular}

The unit root test is widely popular over the past several years for the nature of stationarity. When the number of observation is low, unit root test have a little power (Chebbi and Boujelbene, 2008). The purpose of unit root test is to determine whether the series is consistent with I (1) process with a stochastic trend, or if it is consistent with I (0) process, which means it is stationary, with a deterministic trend. It is essential to examine the stationarity of the variables before the specification and estimation of co-integration. The unit root test results from 2007 to 2017 of all the indices daily time series is not stationary at the level form but all the variables are stationary at the first difference which implies that the indices are integrated of order one, I(1). The outcomes of unit root test are providing the base for the application of Co-integration on this time series data.

\section{Table-5 Johansen Co-integration test}

Table-5a. Johansen Co-integration test: Unrestricted Co-integration Rank Test (Trace)

\begin{tabular}{|c|c|c|c|c|}
\hline Hypothesized & & Trace & 0.05 & \\
\hline No. of CE(s) & Eigenvalue & Statistic & Critical Value & Prob.*** \\
\hline $\mathrm{r}=\mathrm{O}^{*}$ & 0.224630 & 6138.484 & 334.9837 & 1.0000 \\
\hline$r>1$ & 0.216955 & 5475.988 & 285.1425 & 0.0000 \\
\hline$r>2$ & 0.203682 & 4839.142 & 239.2354 & 1.0000 \\
\hline$r>3$ & 0.198448 & 4246.063 & 197.3709 & 1.0000 \\
\hline$r>4$ & 0.179873 & 3670.045 & 159.5297 & 1.0000 \\
\hline$r>5$ & 0.178050 & 3153.682 & 125.6154 & 1.0000 \\
\hline$r>6$ & 0.170744 & 2643.099 & 95.75366 & 1.0000 \\
\hline$r>7$ & 0.167597 & 2155.562 & 69.81889 & 1.0000 \\
\hline$r>8$ & 0.162854 & 1677.887 & 47.85613 & 1.0000 \\
\hline$r>9$ & 0.151589 & 1215.009 & 29.79707 & 1.0000 \\
\hline$r>10$ & 0.146791 & 786.9376 & 15.49471 & 0.0001 \\
\hline$r>11$ & 0.133638 & 373.5499 & 3.841466 & 0.0000 \\
\hline
\end{tabular}

Trace test indicates 12 cointegrating eqn(s) at the 0.05 level

* denotes rejection of the hypothesis at the 0.05 level 
Table-5b. Johansen Co-integration test: Unrestricted Co-integration Rank Test (Maximun Eigen value)

\begin{tabular}{l|l|l|l|l}
\hline Hypothesized & & Max-Eigen & 0.05 & Prob.** \\
\hline No. of CE(s) & Eigenvalue & Statistic & Critical Value & 0.0001 \\
\hline$r=0^{*}$ & 0.224630 & 662.4959 & 76.57843 & 0.0001 \\
\hline$r>1$ & 0.216955 & 636.8462 & 70.53513 & 0.0001 \\
\hline$r>2$ & 0.203682 & 593.0789 & 64.50472 & 0.0001 \\
\hline$r>3$ & 0.198448 & 576.0186 & 58.43354 & 0.0001 \\
\hline$r>4$ & 0.179873 & 516.3629 & 52.36261 & 0.0001 \\
\hline$r>5$ & 0.178050 & 510.5826 & 46.23142 & 0.0001 \\
\hline$r>6$ & 0.170744 & 487.5373 & 40.07757 & 0.0001 \\
\hline$r>8$ & 0.167597 & 477.6749 & 33.87687 & 0.0001 \\
\hline$r>9$ & 0.162854 & 462.8779 & 21.58434 & 0.0001 \\
\hline$r>10$ & 0.151589 & 428.0717 & 14.26460 & 0.0001 \\
\hline$r>11$ & 0.146791 & 413.3877 & 3.841466 & 0.0000 \\
\hline
\end{tabular}

Max-eigenvalue test indicates 12 co-integrating eqn(s) at the 0.05 level

* denotes rejection of the hypothesis at the 0.05 level

Johansen $(1988 ; 1991)$ has developed two methods for testing the number of co-integration vectors. One is Trace test and the other is maximal Eigen values test. In co-integration test, data must be integrated of the same order in nature. For testing the long run relationship, co-integration test is applicable which is matched to the capital market general statement. Theoretically, the Capital market is a suitable place for long run investments. From the above table the result shows that there is a long run association between or among the variables. This means that Shariah compliant stock index moves together with the Conventional composite index and selected sectorial indices in the long run. The result of the Johansen co-integration (Maximum Eigen value) test rejects the null hypothesis and accepts the alternative hypothesis. This means that there is co-integration among the variables. There are two standardized theorems for further test of standard time series techniques. If it passes the cointegration criteria, further procedure is the Vector Error Collection Model (VECM). If it does not full fill the cointegration criteria, it is better to move to the Vector Error Collection Model (VECM) techniques.

\subsection{Vector Error Collection Model (VECM)}

Prior result on co-integration test shows that there is the long run association of the Islamic stock index with conventional and sectorial indices in Bursa Malaysia, which means that at least one of the stocks index stands on opposite direction of null hypothesis and same direction of alternative hypothesis. In this context it is necessary to investigate the nature of co-movements among the stock indices in Bursa Malaysia. The Vector Error Collection Model (VECM) shows us to differentiate between long and short run associations among the Shariah compliant stock index, conventional index and sectorial indices. Moreover, VECM techniques assist to find out the endogenous (dependent) and exogenous (independent) variables among the stocks indices. For long term relationship general specification for VECM is as follows from Table -6 (Appendix). The innovation of adjustment for EMAS is 1 per cent, whereas KLCI has little bit slower speed of adjustment $1.43 \%$. It means that EMAS stock index goes back to equilibrium faster than KLCI. But the speed of adjustment of FINA drives to equilibrium is much faster than all variables. During the sample period EMAS equation shows that in the short run return depends on its lagged criteria because different lag criteria shows different values of the return itself. In the short run, there are short run relationship between KLCI and EMAS. Except CONT, TECH and PRPT, all of the variable show the short run relationship with each other at different lag levels. 
Table-6. Granger Causality test

\begin{tabular}{|c|c|c|c|c|c|}
\hline Null Hypothesis: & F-Statistic & P-Value & Result & Remarks & \\
\hline $\begin{array}{l}\text { LKLCI does not Granger Cause } \\
\text { LEMAS }\end{array}$ & 2.2387 & 0.1068 & $\begin{array}{l}\text { KLCI does not cause } \\
\text { EMAS }\end{array}$ & $\begin{array}{l}\text { Since } \quad \mathrm{P}>5 \% \\
\text { Insignificant }\end{array}$ & \\
\hline $\begin{array}{l}\text { LEMAS does not Granger Cause } \\
\text { LKLCI }\end{array}$ & 4.65999 & $0.0095 * *$ & $\begin{array}{l}\text { EMAS does cause } \\
\text { KLCI }\end{array}$ & $\begin{array}{l}\text { Since } \quad \mathrm{P}<5 \% \\
\text { Significant }\end{array}$ & \\
\hline $\begin{array}{l}\text { LFINA does not Granger Cause } \\
\text { LEMAS }\end{array}$ & 4.80068 & $0.0083 * *$ & $\begin{array}{lll}\text { FINA does } & \text { cause } \\
\text { EMAS } & & \\
\end{array}$ & $\begin{array}{l}\text { Since } \quad \mathrm{P}<5 \% \\
\text { Significant }\end{array}$ & \\
\hline $\begin{array}{l}\text { LEMAS does not Granger Cause } \\
\text { LFINA }\end{array}$ & 7.80706 & $0.0004 * *$ & $\begin{array}{l}\text { EMAS does cause } \\
\text { FINA }\end{array}$ & $\begin{array}{l}\text { Since } \quad \mathrm{P}<5 \% \\
\text { Significant }\end{array}$ & \\
\hline $\begin{array}{l}\text { LINDP does not Granger Cause } \\
\text { LEMAS }\end{array}$ & 2.39011 & $0.0918^{*}$ & $\begin{array}{ll}\text { INDP } & \text { does } \\
\text { EMAS } & \\
\end{array}$ & $\begin{array}{l}\text { Since } \quad \mathrm{P}<1 \% \\
\text { Significant }\end{array}$ & \\
\hline $\begin{array}{l}\text { LEMAS does not Granger Cause } \\
\text { LINDP }\end{array}$ & 3.92783 & $0.0198 * *$ & $\begin{array}{l}\text { EMAS does cause } \\
\text { INDP }\end{array}$ & $\begin{array}{l}\text { Since } \quad \mathrm{P}<5 \% \\
\text { Significant }\end{array}$ & \\
\hline $\begin{array}{l}\text { LINDS does not Granger Cause } \\
\text { LEMAS }\end{array}$ & 0.97848 & 0.376 & $\begin{array}{l}\text { INDS does not cause } \\
\text { EMAS }\end{array}$ & $\begin{array}{l}\text { Since } \quad \mathrm{P}>5 \% \\
\text { Insignificant }\end{array}$ & \\
\hline $\begin{array}{l}\text { LEMAS does not Granger Cause } \\
\text { LINDS }\end{array}$ & 15.9644 & $1.00 \mathrm{E}-07$ & $\begin{array}{l}\text { EMAS does not cause } \\
\text { INDS }\end{array}$ & $\begin{array}{l}\text { Since } \quad \mathrm{P}>5 \% \\
\text { Insignificant }\end{array}$ & \\
\hline $\begin{array}{l}\text { LPLNT does not Granger Cause } \\
\text { LEMAS }\end{array}$ & 1.38036 & 0.2517 & $\begin{array}{l}\text { PLNT does not cause } \\
\text { EMAS }\end{array}$ & $\begin{array}{l}\text { Since } \quad \mathrm{P}>5 \% \\
\text { Insignificant }\end{array}$ & \\
\hline $\begin{array}{l}\text { LEMAS does not Granger Cause } \\
\text { LPLNT }\end{array}$ & 7.70453 & 0.0005 & $\begin{array}{l}\text { EMAS does cause } \\
\text { PLNT }\end{array}$ & $\begin{array}{l}\text { Since } \quad \mathrm{P}<5 \% \\
\text { Significant }\end{array}$ & \\
\hline $\begin{array}{l}\text { LPRPT does not Granger Cause } \\
\text { LEMAS }\end{array}$ & 4.93989 & 0.0072 & $\begin{array}{lll}\text { PRPT does cause } \\
\text { EMAS }\end{array}$ & $\begin{array}{l}\text { Since } \quad \mathrm{P}<5 \% \\
\text { Significant }\end{array}$ & \\
\hline $\begin{array}{l}\text { LEMAS does not Granger Cause } \\
\text { LPRPT }\end{array}$ & 1.99902 & 0.1357 & $\begin{array}{l}\text { EMAS does not cause } \\
\text { PRPT }\end{array}$ & $\begin{array}{l}\text { Since } \quad \mathrm{P}>5 \% \\
\text { Insignificant }\end{array}$ & \\
\hline $\begin{array}{l}\text { LTECH does not Granger Cause } \\
\text { LEMAS }\end{array}$ & 1.28957 & 0.2756 & $\begin{array}{l}\text { TECH does not cause } \\
\text { EMAS }\end{array}$ & $\begin{array}{l}\text { Since } \quad \mathrm{P}>5 \% \\
\text { Insignificant }\end{array}$ & \\
\hline $\begin{array}{l}\text { LEMAS does not Granger Cause } \\
\text { LTECH }\end{array}$ & 0.05025 & 0.951 & $\begin{array}{l}\text { EMAS does not cause } \\
\text { TECH }\end{array}$ & $\begin{array}{l}\text { Since } \quad \mathrm{P}>5 \% \\
\text { Insignificant }\end{array}$ & \\
\hline $\begin{array}{l}\text { LTINM does not Granger Cause } \\
\text { LEMAS }\end{array}$ & 3.45021 & 0.0319 & $\begin{array}{lll}\text { TINM } & \text { does } & \text { cause } \\
\text { EMAS } & & \end{array}$ & $\begin{array}{l}\text { Since } \quad \mathrm{P}<5 \% \\
\text { Significant }\end{array}$ & \\
\hline $\begin{array}{l}\text { LEMAS does not Granger Cause } \\
\text { LTINM }\end{array}$ & 17.6107 & $3.00 \mathrm{E}-\mathrm{O} 8$ & $\begin{array}{l}\text { TINM does not cause } \\
\text { EMAS }\end{array}$ & $\begin{array}{l}\text { Since } \quad \mathrm{P}>5 \% \\
\text { Insignificant }\end{array}$ & \\
\hline $\begin{array}{l}\text { LTRDS does not Granger Cause } \\
\text { LEMAS }\end{array}$ & 3.68663 & 0.0252 & $\begin{array}{l}\text { TRDS does cause } \\
\text { EMAS }\end{array}$ & $\begin{array}{l}\text { Since } \quad \mathrm{P}<5 \% \\
\text { Significant }\end{array}$ & \\
\hline $\begin{array}{l}\text { LEMAS does not Granger Cause } \\
\text { LTRDS }\end{array}$ & 1.17901 & 0.3077 & $\begin{array}{l}\text { EMAS does not cause } \\
\text { TRDS }\end{array}$ & $\begin{array}{l}\text { Since } \quad \mathrm{P}>5 \% \\
\text { Insignificant }\end{array}$ & \\
\hline $\begin{array}{l}\text { LCONT does not Granger Cause } \\
\text { LEMAS }\end{array}$ & 0.02819 & 0.9722 & $\begin{array}{l}\text { CONT does not cause } \\
\text { EMAS }\end{array}$ & $\begin{array}{l}\text { Since } \quad \mathrm{P}>5 \% \\
\text { Insignificant }\end{array}$ & \\
\hline $\begin{array}{l}\text { LEMAS does not Granger Cause } \\
\text { LCONT }\end{array}$ & 6.64438 & 0.0013 & $\begin{array}{l}\text { EMAS does cause } \\
\text { CONT }\end{array}$ & $\begin{array}{l}\text { Since } \quad \mathrm{P}<5 \% \\
\text { Significant }\end{array}$ & \\
\hline $\begin{array}{l}\text { LCNSU does not Granger Cause } \\
\text { LEMAS }\end{array}$ & 0.85332 & 0.4261 & $\begin{array}{l}\text { CNSU does not cause } \\
\text { EMAS }\end{array}$ & $\begin{array}{l}\text { Since } \quad \mathrm{P}>5 \% \\
\text { Insignificant }\end{array}$ & \\
\hline $\begin{array}{l}\text { LEMAS does not Granger Cause } \\
\text { LCNSU }\end{array}$ & 21.5476 & $5.00 \mathrm{E}-10$ & $\begin{array}{l}\text { EMAS does not cause } \\
\text { CNSU }\end{array}$ & $\begin{array}{l}\text { Since } \quad \mathrm{P}>5 \% \\
\text { Insignificant }\end{array}$ & \\
\hline
\end{tabular}

Tables-7 shows that there are bi-directional, unidirectional and no causality relationships among the variables. Since EMAS is the targeted variables, this study tries to find out the relationship between Shariah compliant stock index (EMAS) and sectorial indices (KLCI, FINA, INDP, INDS, PLNT, PRPT, TECH, TINM, TRDS, CONT and CNSU). It reveals that there are two way relationships which indicate the bidirectional causality between EMAS and FINA, EMAS and INDP. But there are unidirectional relationship between EMAS and KLCI, EMAS and PLNT, EMAS and CONT as well. Interestingly it shows that there is one way relationship between PRPT and EMAS, TINM and EMAS, TRDS and EMAS. But there are no causality relationship between EMAS and INDS, EMAS and TECH, EMAS and CNSU. 


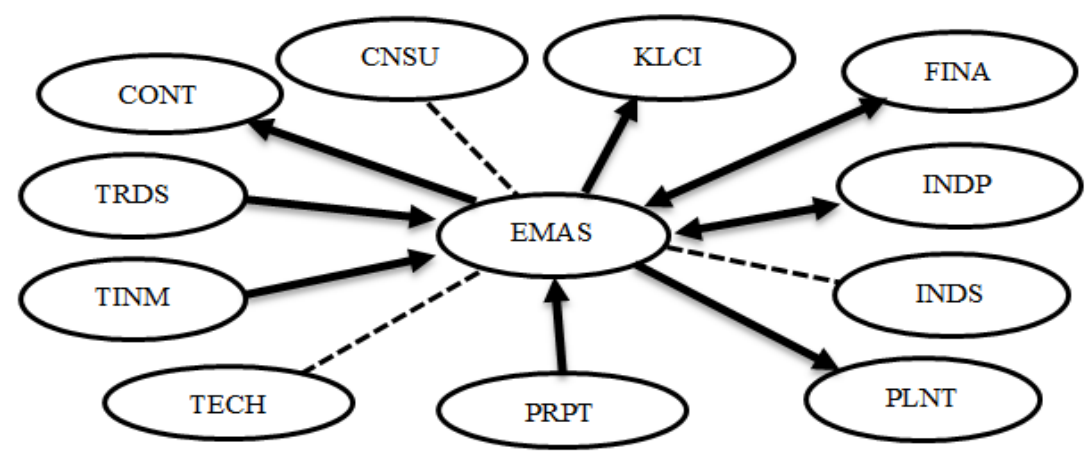

Unidirectional causality Bi-directional causality No causality

\section{CONCLUSION AND RECOMMENDATIONS}

This study has attempted to investigate empirically the co-movement of Shariah compliant stock index (EMAS) with composite index (KLCI) and ten sectorial indices (FINA, INDP, INDS, PLNT, PRPT, TECH, TINM, TRDS, CONT and CNSU) in Bursa Malaysia. Based on the result it has been showed that EMAS Shariah index has the highest mean return respectively as compared to Kuala Lumpur Composite index (KLCI). But from the sectorial indices, FINA has earned the highest return among all sectorial indices, EMAS Shariah index and KLCI composite index. The Co-integration test shows that there is the long run association among the variables. Therefore, over the period of time variables move together which is the main theme of the financial term comovement. But in the short run, the speed of adjustment of EMAS is faster than KLCI which is desirable within the context of Islamic finance in Malaysia. In addition, Granger causality test revealed that EMAS is the concentrated index which shows bidirectional causality with FINA and INDS. Moreover, there exists unidirectional causality between EMAS and PLNT, EMAS and PRPT, EMAS and TINM, EMAS and TRDS, EMAS and CONT. Surprisingly, there are no causality relationships between EMAS and INDS, EMAS and TECH, EMAS and CNSU. This is the limitation of this present study. Hence, further study might consider many other indices to be included which would create additional or even diverse results like Hijarah Shariah index, small cap industries index, mid cap industries index. The findings of co-integration and VECM test provide a proper signal of the efficient investment decision to the investors and policy makers which will assist the investors to have the proper understanding of Shariah compliant market behavior in Bursa Malaysia which is consistent with other studies such as Hoque (2007).

Funding: This study received no specific financial support.

Competing Interests: The authors declare that they have no competing interests.

Contributors/Acknowledgement: All authors contributed equally to the conception and design of the study.

\section{REFERENCES}

Abdullah, A.M., B. Saiti and M. Masih, 2016. The impact of crude oil price on Islamic stock indices of South East Asian countries: Evidence from MGARCH-DCC and wavelet approaches. Borsa Istanbul Review, 16(4): 219-232. View at Google Scholar | View at Publisher

Alaoui, A.O.E., O.I. Bacha, M. Masih and M. Asutay, 2016. Shari'ah screening, market risk and contagion: A multi-country analysis. Journal of Economic Behavianor \& Organization, 132: 93-1 12. View at Google Scholar $\mid$ View at Publisher

Alaoui, A.O.E., G. Dewandaru, R.S. Azhar and M. Masih, 2015. Linkages and comovement between international stock market returns: Case of Dow Jones Islamic Dubai financial market index. Journal of International Financial Markets, Institutions and Money, 36(5): 53-70. View at Google Scholar | View at Publisher

Albaity, M. and R. Ahmad, 2008. Performance of Syariah and composite indices: Evidence from Bursa Malaysia. Asian Academy of Management Journal of Accounting and Finance, 4(1): 23-43. View at Google Scholar 
Albaity, M. and R. Ahmad, 2011. A comparative analysis of the firm specific determinants of syariah compliant versus nonsyariah compliant firms in Bursa Malaysia. Asian Journal of Business and Accounting, 4(1): 59-84. View at Google Scholar

Bursa Malaysia, 2016. Retrieved from http://www.bursamalaysia.com/corporate/about-us/holidays/.

Chebbi, H.E. and Y. Boujelbene, 2008. CO2 emissions, energy consumption and economic growth in Tunisia. 12th Congress of the European Association of Agricultural Economists.

Dharani, M. and P. Natarajan, 2011. Equanimity of risk and return relationship between Shariah index and general index in India. Journal of Economics and Behavioral Studies, 2(5): 213-222. View at Google Scholar

Engle, R.F. and C.W. Granger, 1987. Co-integration and error correction: Representation, estimation, and testing. Econometrica: Journal of the Econometric Society, 55(2): 251-276. View at Google Scholar $\mid$ View at Publisher

Girard, E. and M. Hassan, 2008. Is there a cost to faith-based investing: Evidence from FTSE islamic indices. Journal of Investing, 17(4): 112-121. View at Google Scholar | View at Publisher

Guyot, A., 2011. Efficiency and dynamics of Islamic investment: evidence of geopolitical effects on Dow Jones Islamic market indexes. Emerging Markets Finance and Trade, 47(6): 24-45. View at Google Scholar | View at Publisher

Hoque, H.A., 2007. Co-movement of bangladesh stock market with other markets co-integration and error correction approach. Managerial Finance, 33(10): 810-820. View at Google Scholar | View at Publisher

Islamic, B.M.B., 2011. Global Islamic Finance Report (GIFR) 2011.

Johansen, S., 1988. Statistical analysis of cointegration vectors. Journal of Economic Dynamics and Control, 12(2-3): 231-254. View at Google Scholar | View at Publisher

Johansen, S., 1991. Estimation and hypothesis testing of cointegration vectors in Gaussian vector autoregressive models. Econometrica: Journal of the Econometric Society, 59(6): 1551-1580. View at Google Scholar | View at Publisher

Karim, B.A., E. Datip and M.H.M. Shukri, 2014. Islamic stock market versus conventional stock market. International Journal of Economics, Commerce and Management United Kingdom, 2(11): 1-9. View at Google Scholar

Kim, M.H. and L. Sun, 2017. Dynamic conditional correlations between Chinese sector returns and the S\&P 500 index: An interpretation based on investment shocks. International Review of Economics \& Finance, 48: 309-325. View at Google Scholar $\mid$ View at Publisher

Majid, M. and S.H. Kassim, 2010. Potential diversification benefits across global islamic equity markets. Journal of Economic Cooperation \& Development, 31(4): 103-126. View at Google Scholar

Mensi, W., S. Hammoudeh, A. Sensoy and S.M. Yoon, 2017. Analysing dynamic linkages and hedging strategies between islamic and conventional sector equity indexes. Applied Economics, 49(25): 2456-2479. View at Google Scholar $\mid$ View at Publisher

Rizvi, S.A.R. and S. Arshad, 2014. An empirical study of Islamic equity as a better alternative during crisis using multivariate GARCH DCC. Islamic Economic Studies, 22(1): 159-184. View at Google Scholar | View at Publisher

Rizvi, S.A.R. and S. Arshad, 2017. Analysis of the efficiency-integration nexus of Japanese stock market. Physica A: Statistical Mechanics and its Applications, 470: 296-308. View at Google Scholar $\mid$ View at Publisher answerable for any loss, damage or liability etc. caused in relation to/arising out of the use of the content. 